\title{
PELATIHAN MEMBUAT HANTARAN PERNIKAHAN PADA IBU-IBU RUMAH TANGGA UNTUK MENINGKATKAN PENGETAHUAN DAN KETERAMPILAN
}

\author{
Rini Anggraini'; Popy Yuliarty ${ }^{2}$ \\ ${ }^{1}$ Prodi Teknik Mesin, Universitas Mercu Buana, jl.Meruya Selatan No.1 Kembangan Jakbar \\ ${ }^{2}$ Prodi Teknik Industri, Universitas Mercu Buana, jl.Meruya Selatan No.1 Kembangan Jakbar \\ rini_anggraini@mercubuana.ac.id
}

\begin{abstract}
Abstrak. Hantaran pernikahan atau sering disebut seserahan merupakan sesuatu yang umum dan harus ada dalam rangkaian pernikahan di Indonesia. Seserahan merupakan simbolisasi dari pihak mempelai pria sebagai wujud tanggung jawab kepada pihak keluarga terutama orang tua calon pengantin wanita. Pelatihan ini merupakan pelatihan tahap ke 2 dengan peserta yang berbeda. Permasalahan yang timbul adalah banyak para ibu yang tidak mengetahui cara membuat hantaran pernikahan dengan kreatif dan menarik, padahal keterampilan ini tentu sangat diperlukan untuk mereka sendiri ataupun dapat menjadi peluang jasa menghias hantaran pernikahan. Evaluasi pelaksanaan kegiatan pengabdian masyarakat ini dilakukan dengan cara penyebaran kuisiober kepada peserta yang berjumlah 10 orang. secara umum, kegiatan ini dapat dikatagorikan berhasil, peserta antusias mempelajari dan mempraktekkan materi pelatihan. Namun waktu pelaksanaannya kurang lama sehingga mereka minta waktu selanjutnya untuk belajar lagi ( Nilai rata-rata terendah pada pertanyaan nomor 4 dengan rata-rata $3.10)$
\end{abstract}

Kata kunci : pelatihan,hantaran,keterampilan

\section{PENDAHULUAN}

Hantaran pernikahan atau sering disebut seserahan merupakan sesuatu yang umum dan harus ada dalam rangkaian pernikahan di Indonesia. Hantaran pernikahan atau seserahan yang dulu tidak wajib hukumnya kini sudah menjadi budaya dalam masyarakat Indonesia. Seserahan merupakan simbolisasi dari pihak mempelai pria sebagai wujud tanggung jawab kepada pihak keluarga terutama orang tua calon pengantin wanita. Untuk adat istiadat di Jawa misalnya Jawa Tengah dan Jawa Timur) biasanya seserahan diberikan pada saat malam sebelum dilaksakannya pernikahan pada acara midodareni untuk adat Jawa dan ngenyeuk seureuh untuk adat Sunda, tetapi ada juga yang dilaksanakan pada saat pernikahan. Untuk isi hantaran, walaupun diberikan oleh pihak keluarga pria, namun dewasa ini calon mempelai wanita biasanya diajak untuk memilih barang yang akan dibuat seserahan. Hal ini agar barang seserahan benar-benar bisa dipakai oleh pengantin wanita, sehingga tidak menumpuk saja karena tidak sesuai selera atau malah tidak pas dengan ukuran mempelai wanita.
Setiap tahun terjadi peningkatan pasangan yang akan menikah, bisnis menghias hantaran pernikahanpun telah menjamur dengan tarif yang beragam tergantung tingkat kesulitannya. Namun keterampilan untuk menghias seserahan dapat dikatakan tidak banyak orang yang mampu mengerjakannya, olah karena itu dengan pelatihan ini diharapkan dapat memberikan keterampilan kepada para ibu rumah tangga agar dapat membuat sendiri hantaran pernikahan ataupun dapat dimanfaatkan untuk peluang bisnis rumahan.

\section{Permasalahan Mitra}

Pelatihan ini merupakan pelatihan tahap ke 2 dengan peserta yang berbeda. Calon peserta pada pelatihan ini adalah para ibu yang salah satunya pernah mengetahui adanya pelatihan pembuatan hantaran pada periode yang lalu, kemudian secara lisan para ibu ini meminta untuk dilakukan lagi tetapi dengan materi yang lebih lengkap mencakup semua material / bahan untuk seserahan tidak terbatas pada handuk saja. 
Permasalahan yang timbul adalah banyak para ibu yang tidak mengetahui cara membuat hantaran pernikahan dengan kreatif dan menarik, padahal keterampilan ini tentu sangat diperlukan untuk mereka sendiri ataupun dapat menjadi peluang jasa menghias hantaran pernikahan. Berdasarkan analisis situasi yang terdapat disekitar kami, ternyata banyak para ibu yang berminat mempelajari keterampilan ini namun tidak ada kesempatan karena keterbatasan biaya untuk mengadakan pelatihan ini dengan jumlah peserta yang banyak sekaligus. Mahalnya biaya pelatihan untuk kursus keterampilan membuat hantaran lamaran ini membuat para ibu serta remaja enggan belajar (Rp 2.000.000,- untuk pelatihan selama 5 hari, sumber http://pernikcantikpernikcantik.blogspot.co.id/2011/03/pelatihanhantaran-pengantin-seserahan.html ) jika harus mengeluarkan biaya sebesar itu. Sasaran pelatihan ini yaitu para ibu-ibu rumah tangga disekitar lokasi pelaksanaan abdimas.

\section{Target}

Target dalam pelatihan ini adalah para ibu rumah tangga yang kesehariannya berada di rumah atau bukan wanita karier, dengan pelatihan ini diharapkan mereka mampu mempraktekannya sendiri di kehidupannya sehari-hari, dengan keterampilan ini diharapkan mereka dapat menghias sendiri hantaran seserahannya sehingga memotong biaya untuk jasa menghias hantaran juga bisa menjadi bisnis kecil-kecilan untuk tambahan pendapatan mereka sebagai jasa penghias hantaran.

\section{METODE PELAKSANAAN}

\section{Sifat dan Bentuk Kegiatan}

Pelatihan pembuatan hantaran pernikahan dari semua bahan hantaran ini bersifat terbuka untuk para ibu rumah tangga dan para remaja, khususnya di Kota Tangerang. Bentuk metode penyampaiannya adalah pemberian materi dan praktek secara langsung membuat bentuk yang di inginkan. Bentuk hantaran yang akan di buat pertama diberikan oleh pelatih, selanjutnya peserta di motivasi untuk membuat bentukbentuk lain. Peserta juga diberikan informasi mengenai teknik pembuatan dan alat-alat yang diperlukan untuk membuat bentuk. Selain itu, para peserta pelatihan akan diberika wawasan mengenai biaya jasa menghias hantaran lamaran.

\section{Kuisioner}

Kuesioner adalah suatu teknik pengumpulan informasi yang memungkinkan analis mempelajari sikap-sikap, keyakinan, perilaku, dan karakteristik beberapa orang utama di dalam organisasi yang bisa terpengaruh oleh sistem yang diajukan atau oleh sistem yang sudah ada. Dengan menggunakan kuesioner, analis berupaya mengukur apa yang ditemukan dalam wawancara, selain itu juga untuk menentukan seberapa luas atau terbatasnya sentimen yang diekspresikan dalam suatu wawancara. Penggunaan kuesioner tepat bila :

1. Responden (orang yang merenpons atau menjawab pertanyaan) saling berjauhan

2. Melibatkan sejumlah orang di dalam proyek sistem, dan berguna bila mengetahui berapa proporsi suatu kelompok tertentu yang menyetujui atau tidak menyetujui suatu fitur khusu dari sistem yang diajukan.

3. Melakukan studi untuk mengetahui sesuatu dan ingin mencari seluruh pendapat sebelum proyek sistem diberi petunjuk-petunjuk tertentu.

4. Ingin yakin bahwa masalah-masalah dalam sistem yang ada bisa diidentifikasi dan dibicarakan dalam wawancara tindak lanjut.

Kuisioner yang akan disebarkan kepada respondennya (dalam hal ini adalah peserta pelatihan) ditujukan untuk mencari tahu tentang segala sesuatunya mengenai kegiatan yang telah mereka ikuti.

\section{HASIL DAN PEMBAHASAN \\ Pelaksanaan}

Kegiatan ini dilaksanakan di Komutitas ibi-ibu rumah tangga dan dilaksanakan di Jalan Pasar Nyamuk RT 03 RW 10 Cipondoh Makmur Kota Tangerang yang berjarak kurang lebih $11,1 \mathrm{~km}$ dari Universitas Mercubuana Kampus Meruya pada tanggal 10 Januari 2019

\section{Prosedur Kerja}

Langkah-Langkah prosedur kerja pelatihan pembuatan hantaran pernikahan ini sebagai berikut :

Bahan-Bahan yang di butuhkan

1. Semua material yang biasa dipakai sebagai hantaran antara lain kain 
panjang, perlengkapan sholat, handuk, set bed cover, perlengkapan mandi, pakaian dalam dll

2. kertas koran bekas

3. Karet gelang

4. Jarum pentul

5. Kawat hias

6. Gunting

7. Mata tiruan

8. Pita hias

9. Keranjang wadah

10. Kertas krep dan asesoris lain untuk hiasan pembantu

11. Plastik hias

12. Isolasi

Cara Pembuatan (contoh : membuat bentuk udang dari handuk) :

1. Lebarkan handuk
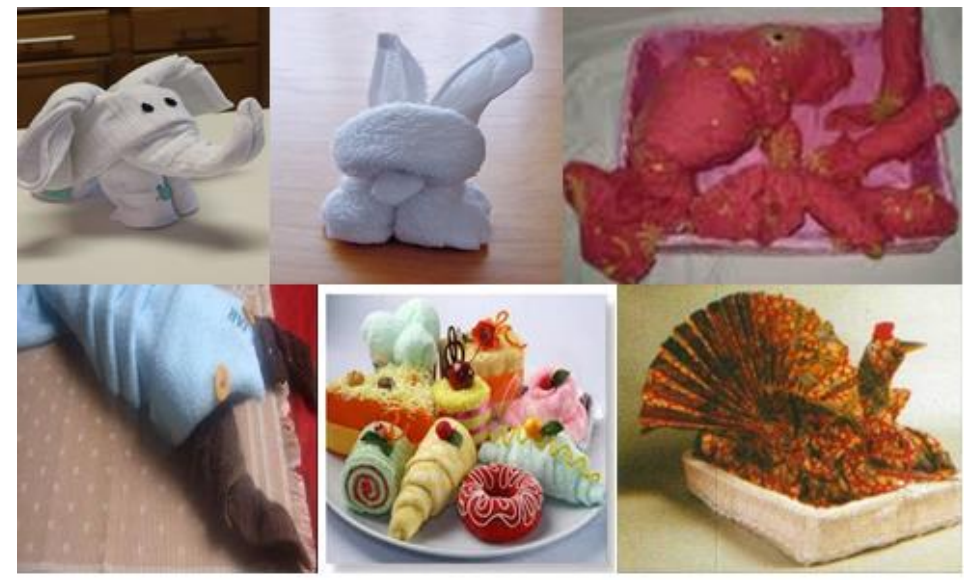

Gambar 1. Contoh bentuk hantaran dari bahan handuk \& kain Panjang

\section{Dokumentasi Kegiatan}

Dokumentasi kegiatan ini dapat dilihat pada Gambar 2berikut ini :

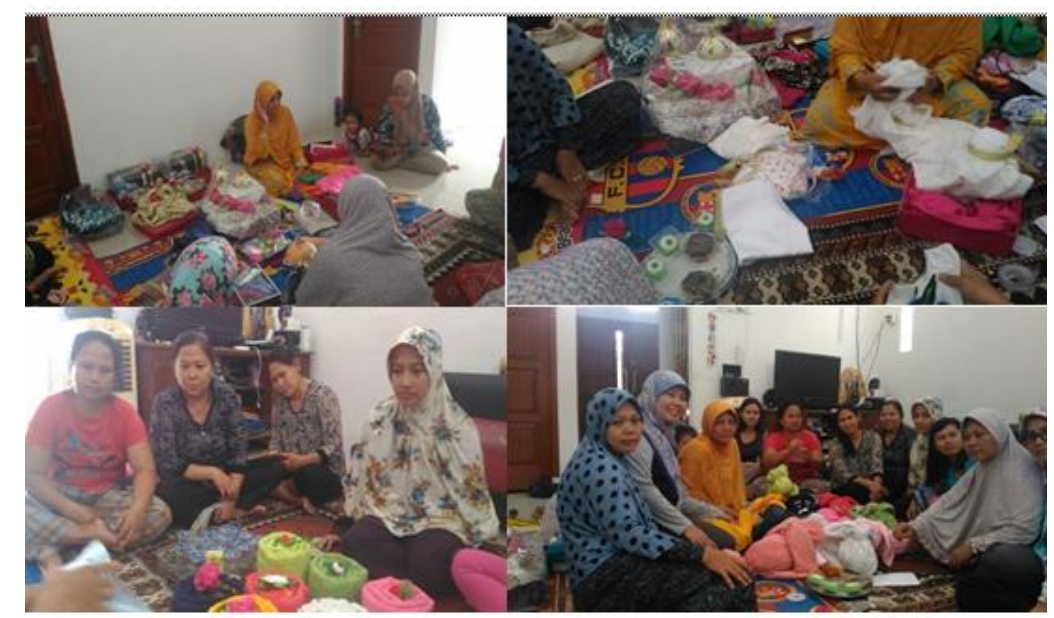

Gambar 2. Dokumentasi Kegiatan
2. Ikat sisi-sisi handuk sesuai bentuk yang diinginkan

3. Buat bentuk, misalnya bentuk badan dan sematkan jarum pentul untuk mempertahankan bentuk yang diinginkan

4. Lakukan pembentukan sesuai ide bentuk yang akan dibuat

5. Beri asesoris tambahan (mata, pita untuk bentuk lurik udang)

6. Lakukan penataan di keranjang tempat handuk bentuk tersebut

7. Bungkus keranjang dan isinya dengan plastik hias mirip hantaran pada umumnya

Gambar 1 berikut ini adalah contoh bentukbentuk yang bisa dibuat.
Gambar 2. Dokumentasi Kegiatan 


\section{Evaluasi Kegiatan}

Evaluasi pelaksanaan kegiatan pengabdian masyarakat ini dilakukan dengan cara penyebaran kuisioner kepada peserta yang berjumlah 10 orang. Tujuan dari kuisioner ini adalah untuk mengevaluasi sejauh mana keberhasilan kegiatan. Hasil rekapitulasi penilaian peserta terhadap tiap kriteria penilaian dapat dilihat pada Tabel 1. di bawah ini :

Tabel 1. Rekapitulasi Kuisioner Evaluasi Kegiatan

\begin{tabular}{|l|l|c|}
\hline No. & \multicolumn{1}{|c|}{ Kriteria yang dinilai } & $\begin{array}{c}\text { Rata- } \\
\text { Rata }\end{array}$ \\
\hline 1. & Kondisi tempat pelaksanaan kegiatan & 4 \\
\hline 2 & Jarak tempat pelaksanaan dengan kediaman peserta & 3.63 \\
\hline 3. & Waktu pelaksanaan kegiatan & 4 \\
\hline 4. & Lamanya waktu pelaksanaan kegiatan & 3.10 \\
\hline 5. & Luas ruangan tempat pelatihan & 3.72 \\
\hline 6. & Ketersediaan alat dan bahan & 3.91 \\
\hline 7. & Penjelasan instruktur tentang cara membuat bentuk hantaran & 4 \\
\hline 8. & Instruktur memotivasi peserta untuk berkreasi sendiri & 3.91 \\
\hline 9. & $\begin{array}{l}\text { Kesediaan instruktur untuk memberi petunjuk bagi peserta yang belum } \\
\text { selesai }\end{array}$ & 4 \\
\hline 10. & Isi / materi pelatihan & 4 \\
\hline 11. & Instruktur menjelaskan alat bantu yang dipakai & 3.81 \\
\hline 12. & Manfaat pelatihan bagi peserta & 4 \\
\hline 13. & Konsumsi bagi peserta & 4 \\
\hline 14. & Uang transport bagi peserta & 4 \\
\hline 15. & Kelanjutan kegiatan yang sama pada masa yang akan datang \\
\hline
\end{tabular}

Berdasarkan nilai rata-rata di atas dapat disimpulkan bahwa secara umum, kegiatan ini dapat dikatagorikan berhasil, peserta antusias mempelajari dan mempraktekkan materi pelatihan. Namun waktu pelaksanaannya kurang lama sehingga mereka minta waktu selanjutnya untuk belajar lagi ( Nilai rata-rata trendah pada pertanyaan nomor 4 dengan ratarata 3.10)

\section{KESIMPULAN}

Kesimpulan yang bisa diambil dari kegiatan pengabdian pada masyarakat ini adalah:

1. Kegiatan telah berhasil dilaksanakan pada Kamis, 10 Januari 2019 dengan peserta ibu-ibu rumah tangga yang berdomisili di daerah Poris RT 03 RW 10 Cipondoh Makmur yang berjarak sekitar 11,5 km dari kampus Universitas Mercubuana Meruya

2. Tidak hanya melaksanakan kegiatan, team juga melakukan evalusai untuk mengetahui sejauh mana keberhasilan dari kegiatan ini. Alat untuk evaluasi menggunakan kuisioner yang

\section{SARAN}

disebarkan dan diisi langsung oleh peserta kegiatan.

Berdasarkan dari urut-urutan kegiatan sampai pada penyelesaian kegiatan, maka saran yang dapat kami brikan yaitu :

1. Kegiatan pengabdian masyarakat seperti ini mendapatkan tanggapan positif dari masyarakat sekitarnya, maka harus terus dikembangkan secara berkelompok dan terprogram.

2. Perlu ada kegiatan lanjutan yang terorganisir untuk melihat dampaknya kepada peserta pelatihan, baik positif maupun negatif untuk menjadi pembelajaran bagi pelaksana.

\section{DAFTAR PUSTAKA}

[1] Djoko Santoso, 2013, Kewirausahaan modul pembelajaran, Direktorat Jendral Pembelajaran dan Kemahasiswaan Ditjen Pendidikan Tinggi Kementerian Pendidikan dan Kebudayaan, Jakarta 
[2] Firyani.Wulan.Ayu, 2012, Ragam Kreasi Lipatan Handuk Cantik Nan Istimewa, Dunia Kreasi,Jakarta

[3] Suharyadi, Arissetyanto Nugroho, Purwanto, SK., dan Mamam Faturohman, 2007, Kewirausahaan: Membangun Usaha Sukses Sejak Usia Dini, Salemba
Empat dan Universitas Mercu Buana, Jakarta

[4] http://noni-

ladies.blogspot.co.id/search/label/Menghi as\%20hantaran

[5] http://www.undangan.web.id/2010/11/me mbuat-hantaran-pengantin-burungmerak.html 